\title{
徳川綱吉政権の武家地政策と幕臣編入家臣団の動向 RELATION BETWEEN SAMURAI LAND (BUKECHI) POLICY AND SHOGUN'S RETAINER ADMISSION DURING TOKUGAWA TSUNAYOSHI GOVERNMENT PERIOD
}

\author{
岩本馨* \\ Kaoru IWAMOTO
}

\begin{abstract}
Based on the residence movement records this paper analyses the samurai residence policy during the Edo Shogunate $5^{\text {th }}$ General administration period, Tsunayoshi Tokugawa (1680 through 1709), a time when the city of Edo developed into a metropolis.

Tsunayoshi had an elder brother, the $4^{\text {th }}$ Tokugawa Shogun Ietsuna, who adopted him. Since Tsunayoshi was the leader of the Tatebayashi clan, when he became Shogun his former vassals from the Tatebayashi clan were admitted as Edo Bakufu retainers. Here I will analyze these Samurai's residence lands. As a result I will show that even after the Tatebayashi clan was abolished, the former Tatebayashi clan's residence land were used as Edo Shogunate retainers land.
\end{abstract}

Keywords: samurai residence lands, Edo Shogunate, Tsunayoshi Tokugawa 武家地, 江戸幕府, 徳川綱吉

\section{1. 問題の所在}

近世巨大都市江戸のうち、7 割弱の面積を占めていたのが武士身分 の居住区としての武家地であった ${ }^{1)}$ 。江戸は幕府の所在地であり、 旗本・御家人の及ならず、全国の大名とその家臣団も集住していた からである。これらの屋敷は原則として幕府から拝領したものであ り、私有地とは異なり幕府の都合次第で強権的に没収・移動させら れる可能性をもつものであった。それゆえ江戸に扭ける武家屋敷の 配置のありようは、その時代の幕府政治の動向と連関するもので あったといえる。

江戸屋敷に関する研究は、鈴木賢次や宮崎勝美らの基礎的な論 考 $^{2)}$ を嚆矢として、その後現在に至るまで多くの蓄積がなされてき ているが3)、政治的動向と屋敷地との関係を検討した研究はそしく、 わずかに役屋敷の成立過程を追った松本剣志郎の論考 ${ }^{4)}$ が成果とし て見られるにとどまっている。一方で政治史の研究においても都市 空間への意識は稀薄である ${ }^{5)}$ 。

こうした流れに対し、筆者はこれまで江戸幕府の政権交代にとも なう屋敷地の変動について研究を行い、政治史と空間史との架橋を 試みてきたが ${ }^{6)}$ 、政権の背後にはその時代固有の事情と論理がある 以上、政治と空間との関係を安易に一般化して論じるのではなく、 事例研究を重ねることで政権の武家地政策の差異を丁寧に評価して
いくことが必要であろう。

そこで本稿で取り上げるのは、5代将軍徳川綱吉政権下に拈ける 江戸屋敷の動向についてである。綱吉は徳川将軍のなかで初めて前 将軍 (ここでは兄家綱) の養子となって将軍職を継承した人物であり、 それ以前は上野「館林藩」(後述するようにこの「藩」は一般の藩とは 異なる特殊な性格を有しており、その意味を込めて本稿では鈎括弧付きで 示す） 25 万石の大名として独自の家臣団を擁していた。したがって 綱吉の将軍家継承々は家臣団の幕臣編入という問題を必然的にとも なうものとなる。この点は筆者がかつて論じた徳川家宣、および吉 宗政権成立期の問題とも共通するが、従前の「藩」のありよう、旧 家臣団の幕臣編入の過程、「藩」の存廃の有無なぞ、事情はそれぞ れ異なっていることにも注意しなければならない。そこで本稿では、 綱吉が将軍であった延宝 8 （1680）年から宝永6（1709）年までを主 たる検討対象として武家屋敷の動向を分析し、それをもとに綱吉政 権の武家地政策の特質を、当該期の政治状況との関係に着目しつつ 明らかにし、併せて家宣扣よび吉宗政権期との比較を行いたい7)。

\section{2. 将軍就任前の綱吉と家臣団 綱吉の前半生}

まず綱吉政権について考える前提として、彼が将軍に就任するまで 
の動向について整理しておく。

綱吉は 3 代将軍徳川家光の五男 ${ }^{8)}$ として正保3 (1646) 年正月 8 日に生まれた。慶安4（1651）年4月3日、父家光の病が篤くなった ことにともない、彼は三男長松（後の綱重）とともに暦料として 15 万石ずつを与えられ、家門大名として取り立てられている。さらに 寛文元 (1661) 年閏8月9日には 10 万石を加増され、上野館林城を 与えられた。ところが延宝 8 (1680) 年4月、綱吉の兄の 4 代将軍 家綱が重体に陥る。この時点で家綱に男子はなく、三男の甲府峷相 綱重も二年前に歿していたことから、重臣の衆議の結果、5月6日 に綱吉が家綱の養子として宗家を継ぐことに決し、翌日綱吉は二丸 に入り、8月23日に5 代将軍となったのである9

\section{綱吉家臣団の形成とその構成}

このように家綱の養子になる前の綱吉は 25 万石の家門大名だった のであり、したがって多くの家臣を抱えていた。綱吉家臣団の形成 過程については深井雅海が詳細に考察して扣り ${ }^{10)}$ 、以下その論点 を整理して扣きたい。

綱吉への家臣附属は正保3（1646）年6月5日に小姓として5人の 幕臣が附けられたのが初見である。その後順次人数は増加していく が、とくに三丸に屋敷を与えられた慶安元（1648）年と 15 万石を 附与された慶安 4 年の両年にまとまった人数が附与されている。

こうして形成されてきた家臣団の状況を示す史料として、『館林

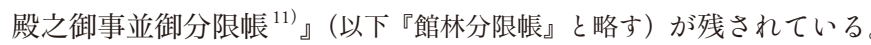
これは寛文3（1663）～4年頃の家臣団名簿であり、総人数は 1,415 人を数える。このうち氏名の記載のある 522 人が士分の家臣と考元 られる。

これら家臣の役職別内訳を表 1 に示す。家臣団は大きく江戸神田 上屋敷勤仕者と、館林勤仕者とに分けられ、このうち前者が 500 人 (95.8\%) と圧倒的多数を占めていた。綱吉自身、居城である館林城 に入ったのは、『常憲院殿御実紀』に見る限り寛文 3 年 5 月のただ 一度のみであり、江戸に常住していた。

神田上屋敷に勤仕する家臣の筆頭は年寄室賀下総守（正俊）6,000 石で、彼を含む年寄衆と、奏者衆・用人衆が家臣団の上層部を占め た。これに加え、書院番・小姓組・小十人組などの番方、勘定・納 戸・右筆などの役方、小姓・小納戸などの近臣の役職が見え、幕府

\section{表 1 『館林分限帳』に見える氏名記載家臣の役職}

\begin{tabular}{|c|c|c|c|c|c|c|c|}
\hline \multicolumn{6}{|c|}{ 神田上屋敷勤仕者 } & \multicolumn{2}{|c|}{ 館林勤仕者 } \\
\hline 役職 & 人 & 役職 & 人 & 役職 & 人 & 役職 & 人 \\
\hline 年寄衆 & 6 & 小姓 & 19 & 蔵奉行 & 4 & 城代 & 1 \\
\hline 奏者衆 & 5 & 表小姓 & 12 & 下屋敷留守居 & 1 & 添城代 & 2 \\
\hline 用人衆 & 7 & 小納戸 & 10 & 医師 & 10 & 足軽大将 & 8 \\
\hline 留守居衆 & 2 & 小姓組 & 49 & 馬方 & 5 & 町奉行 & 2 \\
\hline 書院番頭 & 5 & 書院番 & 58 & 伯楽 & 2 & 書替奉行 & 2 \\
\hline 小姓組番頭 & 5 & 広敷番頭 & 4 & 鷹師 & 7 & 蔵奉行 & 2 \\
\hline 鎗奉行 & 2 & 納戸組頭 & 4 & 同朋 & 2 & 破損奉行 & 2 \\
\hline 持筒弓頭 & 6 & 弓役 & 2 & 小普請 & 22 & 山奉行 & 2 \\
\hline 先手弓鉄炮頭 & 6 & 鉄炮役 & 2 & 破損奉行 & 4 & 鳥見 & 1 \\
\hline 目付衆 & 8 & 小十人組頭 & 5 & 大奥 $メ$ 切番 & 4 & & \\
\hline 使役 & 9 & 賄頭 & 2 & 広敷添番 & 8 & & \\
\hline 書院番組頭 & 5 & 金奉行 & 2 & 徒組頭 & 5 & & \\
\hline 小姓組組頭 & 5 & 納戸 & 4 & 徒目付 & 19 & & \\
\hline 徒頭 & 5 & 右筆 & 6 & 火之番 & 9 & & \\
\hline 小十人頭 & 5 & 領分廻り & 2 & 中間頭 & 2 & & \\
\hline 勘定頭 & 2 & 台所頭 & 2 & 台所方 & 15 & & \\
\hline 寄合 & 1 & 小十人組 & 64 & 茶道方 & 1 & & \\
\hline 納戸頭 & 8 & 勘定 & 23 & 坊主頭 & 3 & & \\
\hline 腰物奉行 & 3 & 書替役 & 2 & 大工頭 & 2 & & \\
\hline 董門番頭 & 4 & 吟味奉行 & 3 & 神田館計 & 500 & 館林計 & 22 \\
\hline
\end{tabular}

組織を縮小したような構成となっていたことがわかる。一方館林勤 仕者は城代大久保荒之助（忠辰）3,000石を筆頭とした士分は 22 人 に過ぎず、ごく少数の陣容で国元の支配にあたっていた。この館林 勤仕者も原則的には交代で派遣されていたようで、たとえばやはり

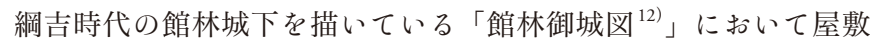
の拝領者名を見ると、『館林分限帳』記載の 22 人のなかで確認でき るのは添城代本多甚左衛門（重盛）、町奉行山川角之丞（忠光）なぞ 6 人に過ぎないことがわかる。館林の武家地には「明地」の記載が 目立ち、武士の存在が稀薄な城下の様相がここからも窥える。これ が「館林藩」が一般の藩と異なる第一の特殊性である ${ }^{13)}$ 。

第二の特殊性として、深井は「館林藩士」の知行のあり方を指摘 している。すなわち、『館林分限帳』で氏名の判明する 522 人のうち、 親子の重複を除き『寛政重修諸家譜』(以下『寬政譜』と略す) で記 載の確認できる 469 人の前歷を調べると、約6割の 293 人が幕臣ま たはその子弟からの附属であったことがわかる（ほかは元大名家臣、 綱吉縁故者、浪人なぞ)。そしてこのうち館林城を与えられた寛文元 (1661) 年以前に附属された家臣は、それ以前に幕府から与えられ ていた本領を、それが「館林藩」領外であっても割替されることな く保持していたという。したがって、彼ら幕臣出身の家臣は、形式 上は「藩士」でありながらも、な打「幕府からの出向者のような存

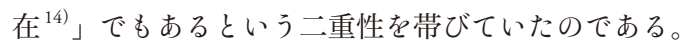

\section{館林家屋敷と「藩士」の江戸屋敷}

この特殊性を屋敷の面からも検討してみたい。綱吉の最初の屋敷 は一橋門内にあり、慶安 4（1651）年7月5日に拝領している(『日 記』、6-674 $\left.{ }^{15)}\right)$ 。ただしこの屋敷は明暦の大火で被災し、明暦 3 (1657) 年 3 月 3 日に神田橋門内に移され (『明暦日記』、7-164)、以後上屋 敷となった。この上屋敷のほか、慶安 5（1652）年 8 月 14 日に小 石川白山に下屋敷を（『公儀日記』、6-760)、万治 3（1660）年に本所 石原に蔵屋敷を拝領している(「南本所石原町書上小 7-328)。

綱吉の家臣団も基本的にはこれらの屋敷内に居住していたものと みられ、上屋敷が万治 4 年 2 月 4 日に (『柳営日次記、7-1059)、下屋 敷が寛文2（1662）年8月14日と同9年8月10日に添地を拝領して 敷地を拡張しているのは（『公儀日記』、8-52/『柳営日次記』8-777)、 家臣団の増加に対応したものであろう。

しかしこれには例外がある。『館林分限帳』と近い時期の江戸図 として、「新板江戸大絵図」・「新板江戸外絵図」（寛文 10 年〜 13 年、 いわゆる「寛文図」）があるが、分限帳の人名を検索すると、522人 中 40 人の名前が発見される (表2)。すなわち彼らは館林家屋敷内 ではなく、幕臣と同様に独立した屋敷を扯領していたことになる。

その内訳をもう少し詳しく見たい。まず年寄衆では 6 人中 5 人、 奏者衆では 5 人中 2 人、用人衆は 7 人全員が独立した屋敷を確認で きる。このうち年寄衆で名前の見えない大久保和泉守 (正朝)につ いては養子で幕臣の名跡古継いだ八郎左衛門 (忠隆) の屋敷が確認 でき、奏者衆で名前の見えない3人はいずれも親兄弟が綱吉家臣で 独立した屋敷を拝領していることから、彼らもそこに同居していた と考えられ、したがって年寄衆・奏者衆・用人衆ら上層部の家臣は 基本的に館林家屋敷外に居住していたことがわかる。

彼らよりも下位の家臣になるとそうした例は少なくなるが、確認 できる家臣の履歴をみるとその大部分は幕臣からの附属者であり (表 1 に打いて附属年がゴシックとなっている家臣)、打そらく幕臣時代 
表 2 「寛文図」で確認される『館林分限帳』所載家臣一覧

\begin{tabular}{|c|c|c|c|c|}
\hline 順 & 名前 & 役職 & 家禄高 附属年 & 屋敷地 \\
\hline 1 & 室賀下総守正俊 & 年寄衆 & 6000石 慶安元 & 小石川門内 \\
\hline 2 & 曽我伊賀守包助 & 年寄衆 & 5000 石 万治 3 & 水道橋外 \\
\hline 3 & (本庄宮内少輔道芳) & 年寄衆 & 4000 石 慶安元 & 小川町 \\
\hline 5 & 黒田信濃守用綱 & 年寄衆 & 3000石 寛文元 & 番町 \\
\hline 6 & 杉浦大隅守政清 & 年寄衆 & 3000石 寛文元 & 小石川 \\
\hline 7 & 牧野兵部成貞 & 奏者衆 & 2500石 万治 3 & 本所 \\
\hline 11 & 金田与三左衛門正勝 & 奏者衆 & 300 俵 寛文元 & 市谷 \\
\hline 12 & 前田孫市郎定次 & 用人衆 & 1700 石 正保 3 & 牛込 \\
\hline 13 & 戸田七内政次 & 用人衆 & 1700 石 正保 3 & 番町 \\
\hline 14 & 柘植平兵衛正弘 & 用人衆 & 1700石 正保 3 & 小川町 \\
\hline 15 & 押田三左衛門直勝 & 用人衆 & 1700石 慶安元 & 番町 \\
\hline 16 & 向坂清左衛門政定 & 用人衆 & 1600 石 正保 3 & 番町 \\
\hline 17 & 植村五郎八 & 用人衆 & 1100 石 慶安元 & 番町 \\
\hline 18 & 山本七郎左衛門正信 & 用人衆 & 1300 石 慶安元 & 駿河台 \\
\hline 22 & 大久保新蔵包教 & 書院番組頭 & 650 俵 慶安元 & 牛込門内 \\
\hline 31 & 武嶋四郎右衛門茂信 & 鎗奉行 & 600俵 寛文 2 & 小日向 \\
\hline 35 & 伏見助左衛門為景 & 持筒弓頭 & 500 俵 慶安元 & 内藤宿 \\
\hline 41 & 中根九郎兵衛正連 & 先手弓鉄炮頭 & 550 俵 寛文2 & 牛込 \\
\hline 45 & 美濃部十右衛門茂之 & 目付衆 & 450 俵 慶安4 & 本所 \\
\hline 52 & 鈴木甚之助重元 & 目付衆 & 450 俵 慶安4 & 番町 \\
\hline 55 & 小佐手五左衛門信忠 & 使役 & 500俵 寛文 2 & 小日向 \\
\hline 64 & 川窪善左衛門信本 & 書院番組頭 & 不明 不明 & 牛込 \\
\hline 66 & (石野弥五左衛門祐正) & 書院番組頭 & 300 俵 慶安4 & 駿河台 \\
\hline 82 & 平野与左衛門勝貞 & 勘定頭 & 500 俵 慶安 4 & 小石川門内 \\
\hline 83 & 柳沢刑部左衛門安忠 & 勘定頭 & 165石 不明 & 市谷 \\
\hline 94 & 仙波弥市左衛門永清 & 腰物奉行 & 220 俵 慶安4 & 番町 \\
\hline 110 & 前田新八郎定相 & 小姓 & 250 俵 (二世) & 番町 \\
\hline 115 & 原田友之助種久 & 小姓 & 200 俵（二世） & 牛込 \\
\hline 118 & 細井喜太郎正貞 & 小姓 & 200 俵 不明 & 本所 \\
\hline 136 & 酒依九兵衛 & 小納戸 & 250 俵 不明 & 番町 \\
\hline 139 & 三嶋五左衛門政房 & 小納戸 & 250 俵 不明 & 番町 \\
\hline 161 & 岩間源三郎正平 & 小姓組 & 220 俵 慶安4 & 市谷 \\
\hline 171 & 石原太郎左衛門正次 & 小姓組 & 220 俵 慶安 4 & 四谷 \\
\hline 203 & 山田友右衛門重時 & 書院番 & 207俵 不明 & 湯島 \\
\hline 217 & 山木五郎左衛門正次 & 書院番 & 200 俵 不明 & 小石川 \\
\hline 227 & 三宅三十郎正永 & 書院番 & 200 俵 不明 & 半蔵門外 \\
\hline 234 & 植村庄兵衛正矩 & 書院番 & 200 俵 不明 & 番町 \\
\hline 353 & 辻源五右衛門守壽 & 蔵奉行 & 不明 不明 & 本所 \\
\hline 413 & (石原太郎兵衛吉次) & 小普請 & 200 石 70 俵 慶安元 & 四谷 \\
\hline 501 & 大久保荒之助忠辰 & 館林城代 & 3000 石 寛文3 & 番町 \\
\hline
\end{tabular}

「㮌」は『館林分限帳』の記載順。括弧付きの人名は「寛文図」時点で故人で後 継者の人名が見えるもの。附属年がゴシックとなっているのは幕臣からの附属を示す。

の拝領屋敷をそのまま保持していたものと考えられる。また新規附 属家臣の例ではいずれも慶安 4 年という初期の附属者であり、これ は深井がすでに指摘しているように、「寬文元年閏八月九日に綱吉 が上州館林二五万石を与えられるまでは将軍家の「家族」同様に扱

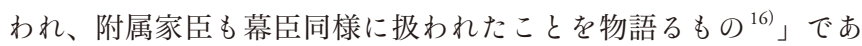
ろう。先述したような幕臣出身家臣にみられる「藩士」と幕臣との 二重性は、屋敷の面でもまた確認できるのである ${ }^{17)}$

\section{3. 綱吉政権期の屋敷移動}

\section{綱吉政権の成立}

すでに触れたとおり、綱吉は延宝 8 (1680) 年 5 月 7 日に兄家綱の 養子として江戸神田上屋敷から江戸城二丸に入っている。翌 5 月 8 日に家綱は薨じているから、この日から綱吉が急死する宝永 6 (1709) 年正月 10 日までの 28 年半ほどが実質的な綱吉政権期とい うことができる。以下ではこの時期の江戸に扣ける武家屋敷の動向 について分析を行いたい。

\section{分析のための史料}

当該期間の屋敷収受について知るために、本稿では以下のような史 料を使用してデータベースを作成した。

(1) 屋敷渡預絵図証文（以下『屋敷証文』とする）：旧幕引継書の一 つで、江戸において屋敷を拝領した者または預けられた者が幕府 普請奉行所に提出した証文である。ここから当該屋敷地の地名・
敷地周辺図（隣接屋敷の拝領者名も含む）・敷地坪数・旧拝領者名 · 新規拝領者名・日付などの情報が判明する（一部建築についての情 報を含むものもある)。国立国会図書館には計 304 冊が現存するが、 原証文を綴じたものと写本との二種類が確認される(内容は同一)。 綱吉政権期では天和元（1681）年〜 3年、元禄 10 （1697）年の本 所の部 ${ }^{18)}$ 、同 11 年 6 月、同年9月の一部に欠落がある。また役屋 敷収受は作成対象外であったとみられ、当該証文は確認できない。

(2) 屋敷書抜：同じく旧幕引継書の一つで、年ごとに屋敷収受の一 覧を書き留めたものである。国立国会図書館には寛文12（1672） 年〜文久3（1863）年までの62冊と、これを再整理した寛文 12 年〜安政7 (1860) 年までの 49 冊が現存する。内容は『屋敷証文』 の抜粋といえるが、こちらには元禄 11 年 6 月・9月の記事も見え るので、欠落部分を補うことができる。

（3) 御府内往還其外沿革図書・御府内場末往還沿革図書（以下『沿 革図書』、『場末沿革図書』とする)：普請奉行の編による江戸の地域 変遷図で、前者は全 15 巻計 168 区画、後者は全 8 巻計 479 区画か らなり、江戸のほぼ全域をカバーする (一部欠落あり $\left.{ }^{19)}\right)$ 。こちら は時期ごとの屋敷の位置が判明するので、証文類と照合させるこ とで屋敷地を具体的に比定させることができる。なお写本は国立 国会図書館・国立公文書館内閣文庫・東京都立公文書館に残る が、本稿では『沿革図書』については都立公文書館本をもとにし た『江戸城下変遷絵図集』(原書房、1985-87年) を、『場末沿革図 書』については国立国会図書館本（ただし欠落の第 18 巻は内閣文庫 本を、本所之部は都立公文書館本）をそれぞれ利用した。

以上 3 つを基本史料として、これに『東京市史稿』市街篇に収録 される屋敷収受関係記事 (1)・(2)の翻刻も含まれる) で遺漏分を補い、 またこれらを寛政譜での幕臣の履歴と照合させることで、綱吉政権 下に扣いて、どのような立場の幕臣が、いつどこにどのような規模 の屋敷を得たのかの動向を追うことができる。この間の新規拝領・ 屋敷移動の総件数は 5,043 件 (場所記載分、大縄扯領屋敷は単位ごと に 1 件と数える）に及び、江戸の武家地では直参の幕臣屋敷の 4 分 の 1 弱が入れ替わるほどの大規模な流動があったことがわかる ${ }^{20)} 。$

\section{屋敷収受の動向}

以下では作成したデータベースにもとづき、政権の意向がとくに反 映していると考えられる屋敷収受の動向について摘記する。

(1) 延宝8（1680）年～9年（天和元年）：この時期には、延宝 8 年 8 月9日に馬場先門内にて牧野備後守成貞が屋敷を洋領したのを皮 切りとして、綱吉に供奉して幕臣化した家臣の屋敷抨領が散見さ れる。この問題については次節で詳しく検討したい。

(2) 天和2（1682）年：この年で注目されるのは、本所からの撤退 にともなう屋敷地の移動である。すなわち、綱吉は天和 2 年 3 月 14日に「本所に宅地ある輩。常に水患をくるしむよし聞ゆれば。 府に転換せん事支のぞまば。ゆ るさるべき旨令 ${ }^{21)} 」$ を発し、万 治元 (1658) 年頃から市街化が 進んでいた本所からの撤退策を 打ち出した。「本所住宅御替地 拝領之衆」(9-1108〜1130) に はこのときの屋敷替が書き上げ られているが、ここに見える大
表 3 本所からの移転先

\begin{tabular}{llr}
\hline 移転先 & 旧拝領者 & 人数 \\
\hline 半蔵門外 & 松平越後守光長 & 40 \\
青山 & 青山大膳亮幸利 & 36 \\
麻布 & 松平三河守綱国 & 20 \\
築地 & 渡辺大隅守綱貞 & 11 \\
小石川 & 真田伊賀守信利 & 10 \\
浅草 & 堀田豊前守正休 & 8 \\
その他 & & 25 \\
\hline 計 & & 150 \\
\hline
\end{tabular}


縄拝領屋敷を除く 150 人の移転先を整理すると表3のようになる。 ここで最も多い半蔵門外と三番目に多い麻布の屋敷は、延宝9年 の越後騒動で改易となった松平光長・綱国父子の元屋敷であった。 四番目に多い築地も同じく越後騒動に連座した渡辺綱貞の元屋敷、 五番目の小石川は御家騒動のために天和元年 11 月 22 日に取り潰 された真田信利の元屋敷であり、このときの屋敷割替には改易大 名の屋敷が用地として活用されていたことが窥える。

(3) 貞享5 (1688) 年 (元禄元年) :この年に入ると綱吉は本所撤退 策を放棄し、再び市街化が始まる。3月5日に 15 人が本所に屋敷 を拝領しているのが初見であるが (『天享吾妻鑑』、10-746)、これ 以降元禄期にかけて数度にわたりまとまった割付を確認できる。

(4) 元禄4 (1691) 年: 2 月 10 日夜、麴町で火災が発生し、周辺の 町家と武家屋敷に被害が及んだ（11-304）。これを契機として幕 府は麴町通り南側一帯を収公して火除地としている。『屋敷証文』 では 2 月中に計 23 人の幕臣が替地を受領しているが、その全て が本所で、かつ 1 人を除いて元坪にボーナス（諏訪因幡守忠晴は 300 坪増、ほか 100 坪増）が加算されている。このように先に述心 た本所の再開発は江戸の防火対策とも連関していたのである。

(5) 元禄6 (1693) 年：2月に本所に沶いて幕臣計 188 人への大規模 な屋敷給賜が確認される(『屋敷証文』、11-531～575)。本所地域の 再開発がいっそう進展したことがわかる。

(6) 元禄7 (1694) 年：6月に小石川において御家人計 56 人のまと まった拝領が確認される（『屋敷証文』、12-74、80～82、105～109）。 これは鷹匠同心組屋敷の跡地であり、前年に生類憐れみの令の一 環として鷹方が廃止されたことによるものであった。

(7) 元禄10（1697）年：10月23日、綱吉は松平出羽守綱近に助役 を命じ、北丸の築造を開始する。これにより、建設予定地にあっ た屋敷は全て移転されられている。またこの年の動向で注目され るのは、11月 14 日引渡の内藤宿内藤丹後守清牧元屋敷に扣ける まとまった屋敷給賜で (『屋敷証文』、13-483〜492)、このとき拝領 した 43 人全員が寄合または小普請、すなわち無役の幕臣であっ た。証文には「元屋敷御用地二被 召上候為御代地」とあり（元 屋敷にとくに共通性は認められない)、いわば余剩人員である無役幕 臣を場末の地に集中させるという綱吉政権の意図を読み取ること ができる。生類憐れみの令との関連では、11月23日に大久保に て大番 12 人に屋敷が引き渡されているが (『屋敷証文』、13-504 507、ここれは手狭のため同月に閉鎖された犬御用屋敷の跡地を分 割したものであった。

(8) 元禄14 (1701) 年 : 深川地域の再開発は本所に比べると遅れ、 元禄 13 年以前までの拝領事例は計 10 件を確認できるのみであっ たが、この年には計56件が確認でき、深川の武家地化が一挙に 進んだことがわかる。

(9) 元禄17（1704）年（宝永元年）：前年11月29日に発生した大火 を受けて、4月15日に本郷御弓町にあった先手組屋敷を関口・駒 込・本所の三箇所に移転させ、その跡地に新たに屋敷地古割り出 している(『天享吾妻鑑』、15-626)。これも災害を契機とした武家 地の再編の例といえる。

(10) 宝永元（1704）年〜 5年：綱吉には後継の男子がなかったこと から、12月5日に甲府家の綱豊を養子とすることを決定する。こ れにともない綱豊家臣団も幕臣に編入されるが、12月11日に間
部越前守詮房が馬場先門内に屋敷を拝領したのを皮切りに(『屋 敷証文』15-792)、以後幕臣化家臣団の屋敷拝領が散見される。 この過程についてはすでに筆者が別稿にて論じている ${ }^{22)}$

\section{小結}

以上、綱吉政権期における屋敷収受の動向を概観したが、武家地の 拡大にともない、隅田川左岸地域 (本所・深川) や小石川・内藤宿・ 大久保などの江戸周縁部の開発が進展してきたこと、大火などの災 害が武家地の再編の契機となっていたこと、生類憐れみの令をはじ めとする政策が屋敷流動とも関連していたことなどがわかった。そ こで次に検討すべきは、綱吉の将軍就任にともなって幕臣化した綱 吉家臣団の屋敷地の動向がこうした全般的動向とどのように関連し ていたかという点である。以下、節を改めて検討したい。

\section{4. 幕臣編入家臣団の屋敷地動向 綱吉家臣団の幕臣編入と「館林藩」}

延宝 8 （1680）年の綱吉の将軍就任は家臣の幕臣編入をともなった が、しかしそれは「館林藩」の廃藩を意味するものではなかった。『常 憲院殿御実紀』によれば、「潜邸（引用者注：神田上屋敷）は徳松君 相続せられ。封地。家人もありしまつたるべしと仰出され ${ }^{23)} 」 と$ あるように、「館林藩主」の座は綱吉の二歳になる男子が継承した からである。これには、家綱臨終の時点でなお披の側室に懐妊の噂 があり、若君誕生の可能性が残されていたためであり ${ }^{24)}$ 、将軍綱 吉は当初はあくまで中継ぎという建て前であった。それゆえ7月 10 日に綱吉が本丸に移ったときに供奉して幕臣となったのは彼に ごく近い家臣数十人にとに゙まったのである。

その他の家臣はな打「館林藩士」として徳松に仕えることとなっ たが、家綱の遺児誕生の可能性がほぼ消滅した 11 月に入ると、徳 松はようやく将軍継嗣と決し、27日に西丸に移り「若君」と呼ば れるようになった。この日から徳松家臣団も西丸の勤仕することと なって幕臣に編入されるが、その後も「館林藩」は廃藩にならず、 彼らは徳松が亡くなる天和3（1683）年までは幕臣でもあり「館林 藩士」でもあるという二重性を有していたことに注意しなければな らない24)。

\section{幕臣編入家臣団の屋敷拝領}

こうした二重性は屋敷拝領に打いても表れている。表 4 は徳松卒去 以前の綱吉家臣団の屋敷择領事例を整理したものである。これによ ると拝領件数は 38 で、延べ 35 人が择領を受けている。このうち 33 人が延宝 8 (1680) 年に綱吉に供奉して本丸入りした幕臣に相当 する。彼らのなかで、それ以前から拝領屋敷を有していたことが確 認されるのは 6 人のみで、ほかは新規拝領であったと考えられる。 また前捧領者の履歷を確認すると、表に挙げられた屋敷の過半数が 改易にともない収公されたものであったことも注目される。深井の 論考によれば、『寛政譜』に記載が見える幕臣編入家臣団は488 家 528 人に扣よび、このうち延宝 8 年に幕府の役職に就いた本丸勤仕 者は 61 人であったこと ${ }^{25)}$ を考えると、本丸勤仕者の全員がすぐ に屋敷を得られたわけではなく、また彼らへの屋敷割り当ても、改 易などで明屋敷が発生したところにそのつど充填していくょうな、 受動的な方法がとられていたことが読み取れる。

徳松に附属され西丸に勤仕していた幕臣の屋敷拝領事例はいっそ う少なく、該当期間では本庄因幡守宗資と柘植五太夫正信の 2 人を 
確認できるのみである。彼ら西丸勤仕者は先に 述べたように幕臣に編入されていながらな打形 式的には「館林藩士」でもあり、したがってな 扣存置されていた館林家屋敷を居住の場として いたと考えられる。本丸勤仕者であっても拝領 屋敷を確認できない家臣もまた同様であったろ う。

\section{徳松死後の旧「藩士」と元屋敷}

徳松は天和 3(1683) 年閏 5 月 28 日に 5 歳で卒 去する。これにともない、館林藩」は廃藩となり、 徳松旧臣は「藩士」との二重性を脱して純粋な 幕臣となる。しかし、延宝 8 (1680) 年に綱吉に 供奉して本丸入りした家臣が幕臣編入後に将軍 近臣や実務吏僚として登用されたのに対し、こ のときの徳松旧臣は西丸側衆と徒・坊主を除く 全員が 6 月 19 日付けで小普請入りとされており、 この「編入」に対する綱吉政権の積極的姿勢は 見えにくい。それゆえ旧「藩士」は徳松の死に より二重身分状態を脱したにもかかわらず、そ のことは必ずしも新規屋敷拝領の契機とはなら なかったのである。実際、その後の屋敷収受の 動向を見ると、彼らのまとまった屋敷拝領とし ては以下の事例が確認される程度にすぎない。

(1) 元禄元（1688）年12月：本所の旧蔵屋敷跡 扣よびその周辺で代官・勘定 23 人が屋敷を受 領している(『屋敷証文』、10-948、963〜980)。

(2) 元禄6 (1693) 年2月:本所に扣いて番医 1 人、

代官 3 人、右筆 5 人、勘定 12 人、二条蔵奉行 1 人、小石川御殿奉 行 1 人の計 23 人が屋敷を受領している（『屋敷証文』、11-535、538 〜575)。

(3) 元禄7（1694）年6月：小石川鷹匠同心組屋敷跡に扮いて広 敷番頭 1 人、広敷添番 2 人、三丸広敷添番 2 人、宝蔵番 1 人、天 守番3人の計 9 人が (『屋敷証文』、12-74〜 75、80 81、105〜109)、 本所に打いて代官 2 人、勘定 2 人、小普請 1 人の計 5 人が（同上 12-84〜88、91〜92) それぞれ屋敷を受領している。

(4) 元禄 11 (1698) 年 2 月：小石川白山に打いて番方 12 人をはじ め旧「藩士」計 20 人が屋敷を受領している(『屋敷証文』、13-643 〜648、653 654)。

(5) 元禄 14 (1701) 年 10 月：内藤宿に扎いて大番 8 人が、小石川 白山に拈いて大番 3 人、小十人 2 人がそれぞれ屋敷を受領してい る(『屋敷証文』、14-899 903)。後者の場所では 12 月にも大番 4 人、 小十人 2 人が屋敷を受領している（同上、14-962 965）。

ここで見られる割り当て地は本所や小石川といった周縁部にあり、 また役職ごとに一定のまとまりが確認される。この点は前節で見た 全般的な傾向とも共通する。ただし期間内で確認される拝領者は『寛 政譜』で確認できる 528 人よりもずっと少なく、また幕臣化を果 たしてからのタイムラグも長い。したがって綱吉政権は、徳松の死 =館林藩廃藩以後も、原則として元屋敷を旧「藩士」の居住の受け 且々する政策を維持したとみるべきであろう。以下、それぞれの元 館林屋敷がいかに活用ないし再編されたかについて検討したい。

\section{神田上屋敷}

神田屋敷は館林家の上屋敷であり、綱吉の住居と政務空間がその中 心的な機能であったと推定される。この屋敷は綱吉の将軍就任後は 「藩主」徳松に継承されたが、徳松自身はその後西丸に入り、家臣 たちもそちらに勤仕したことから、事実上留守邸となっていたと考 えられる。実際、徳松在世中の延宝9（1681）年7月に江戸城二丸 の工事が行われたさいには神田御殿が移されたとの記録も残る ${ }^{26)}$ ただし、その翌天和 2（1682）年 10 月 27 日に綱吉が「神田の御殿

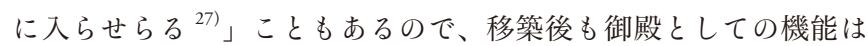
保持していたのであろう。

天和 3 年の徳松の死により「館林藩」が廃藩となってからは、神

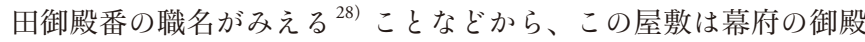
として引き継がれたと考えられる。上屋敷時代打よび幕府御殿時 代に、どれほどの（旧）「藩士」が居住していたかは史料がなく不 明とせざるを得ないが、元禄 13 (1700) 年 8 月 2 日に柳沢出羽守保 明が神田御殿の地を拝領していることから（『柳沢保山一代記』、14487)、遅くともそのときまでに全員が退去したものと考えられる ${ }^{29)}$

\section{小石川白山下屋敷}

小石川白山の下屋敷は現在の東京大学理学系研究科附属植物園（小 石川植物園）とその北東の住宅地付近にあり、前者の部分の土地利 用の変遷については渋谷葉子による考察がある ${ }^{30)}$ 。

第2節で述べたと扣り、綱吉がこの地に下屋敷を拝領したのは慶 安5（1652）年であり、その後寛文2（1662）年と9年に添地をして 
表 5 元禄 11 年時点の小石川白山屋敷跡拝領者

\begin{tabular}{|c|c|c|c|c|}
\hline \# & 屋敷受領日 & 拝領者 & 元禄 11 年時点での役職 & 家禄高 \\
\hline (1) & & 坂入半之丞重信 & 台所頭 & 200俵4口 \\
\hline 2 & 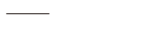 & 岩沢六左衛門教久 & 不明 & 不明 \\
\hline 3 & & 中村庄兵衛尚善 & 小普請方上役， & 不明 \\
\hline (4) & & 深沢仁左衛門正勝 & 勘定 & 不明 \\
\hline 5 & - & 岡室弥五兵衛政徳 & 三丸広敷書役／三丸広身 & 不明 \\
\hline 6 & - & 大塚太右衛門信光 & 三丸台所人 & 不明 \\
\hline 7 & & 中村三郎左衛門勝行 & 新番 & 250 俵 \\
\hline 8 & - & 三浦卢 & 小十人 & 200 供 \\
\hline & - & 窪田 & 十人 & 150 猿 \\
\hline (10) & - & 山下太郎右衛門義方 & 小普請 & 200 猿 \\
\hline (11) & 元禄 11 & 西尾権八郎政蒔 & 勘定 & 100俵3口 \\
\hline (12) & 元禄 2 & 藤井喜右衛門正平 & 三丸賄方／三丸 & 不明 \\
\hline (13) & & 門清信 & 三丸広敷添番 & 200猿 － - \\
\hline (14) & - & 之助義方 & 大番 & 200俵 \\
\hline (15) & 元禄 $2 \cdot 2 \cdot 18$ & 石原与兵衛正盈 & 勘定 & 100 俵3 口 \\
\hline 16 & & 向坂庄兵衛正勝 & 三丸賄頭 & 200 俵 \\
\hline (1) & - & 伏見金右 & 神田普請小屋 & 500 猿 \\
\hline (18) & - & 某 & 三丸 & 不明 \\
\hline (19) & - & 椇武弘 & 西丸裏門 & 不明 \\
\hline 20 & 元禄7 & 志 & 三丸広旉 & 不㫙 \\
\hline (21) & - & 小入 & 三丸台所人 & 不㫙 \\
\hline (22) & 元禄 2 & 宣久 & 小普請 & 現米 120 石 \\
\hline 23 & 元禄 7 & 成海佐左 & 三丸広敷添番 & 不明 \\
\hline (24) & & :衛門 (伝兵衛信是 & 三丸台所人 & 不明 \\
\hline 23 & - & 小野七郎兵衛直救 & 三丸台所人 & 不明 \\
\hline 26 & $\bar{z}$ & 門正房 & 表火番／広敷添番／壽光院添番 & 不明 \\
\hline (27) & 元禄3 & 月正静 & 三丸広敷添番 & 不明 \\
\hline 28 & & 鈴 & 元牧野月 & 300 猿 \\
\hline 29 & & & 小普請 & 350信 \\
\hline (30) & - & 茂敦 & 勘定 & 100 侄 \\
\hline (31) & - & & 番 & 不㫙 \\
\hline 32 & - & & 未襲 & 450猿 \\
\hline 33 & - & & 表奥火 & 不日 \\
\hline 34 & - & 西与 & 代官 & 150俵 \\
\hline 33 & - & 平 (次郎大夫資友?) & 勘定 & 100 俵3口 \\
\hline 36 & - & 大石四郎左衛門 (甚五右衛門道広?) & 大番 & 220 俵 \\
\hline (37) & & 加六 & 小石川御庰 & 200侄 \\
\hline 38 & - & 山 & 大番 & 500 石 \\
\hline 39 & 元禄 $3 \cdot 1$ & 江具 & 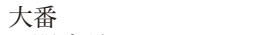 & 300 猿 \\
\hline 40 & - & & & 不月 \\
\hline (41) & - & 長井三郎兵衛忠昌 & 小产 & 220 猿 \\
\hline 42 & 元禄 2 & 間宮上 & & 200 侄 \\
\hline 43 & & 筒井武左衛門(武右衛門政朝?) & 桐間番 & 250 位 \\
\hline
\end{tabular}

番号は図 1 と対応。白抜き番号は旧「館林藩士」を示す。屋敷受領日は『屋敷証文』、

拝領者の諱・役職・家禄高は『寛政譜』による。

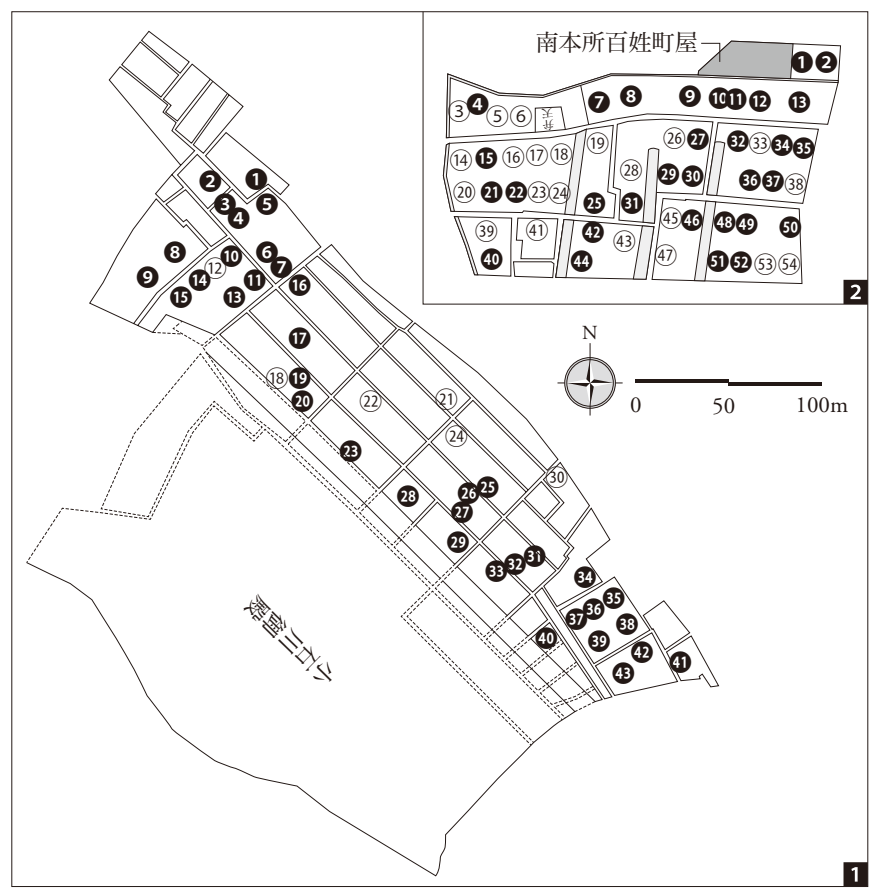

図 1 元禄 11 年頃の旧小石川白山屋敷/図 2 元禄 6年頃の旧本所屋敷

\section{表 6 元禄 6 年時点の本所石原屋敷跡拝領者}

\# 屋敷受領日 拝領者元禄6年時点での役職家禄高

(1) 元禄 $6 \cdot 2 \cdot 6$ 石原与兵衛正盈勘定

2 元禄 $6 \cdot 2 \cdot 6$ 宮重彦右衛門信清

(3) 元禄元 $\cdot 12 \cdot 21$ 久下作左衛門重秀

4 年月不詳 清水庄九郎定道

(5) 元禄元 $\cdot 12 \cdot 21$ 細田三右衛門時春

(6) 元禄元 $\cdot 12 \cdot 21$ 町野新兵衛某

(7) 年月不詳 岡田五右衛門俊易

8 年月不詳山田十右衛門元定

9 年月不詳比企佐左衛門勝信

(1) 年月不詳石原又右衛門政成

(11) 年月不詳 古江左助為利

(12) 年月不詳正木藤右衛門弘信

(3) 年月不詳 山田源左衛門重維

14) 元禄元・12・21 本間小右衛門正堅

(15) 元禄 $6 \cdot 2 \cdot 6$ 水野甚左衛門親信

(16) 元禄 $6 \cdot 2 \cdot 6$ 真崎伊右衛門清長

(17) 元禄 $6 \cdot 2 \cdot 6$ 小野寺作右衛門秀成

(18) 元禄元 $\cdot 12 \cdot 21$ 能勢平右衛門賴寛

(19) 元禄元・ $12 \cdot 21$ 岩出与左衛門某

(20) 元禄元 $\cdot 12 \cdot 21$ 秋田三郎左衛門政森

(21) 元禄 $6 \cdot 2 \cdot 6$ 荻原甚五左衛門友高

22 元禄元 $\cdot 12$ ? 近藤小兵衛忠明

(23) 元禄元 $\cdot 12 \cdot 21$ 宇田川平兵衛忠成

(24) 元禄元 $\cdot 12 \cdot 21$ 秋山彦大夫幸常

29 年月不詳遠藤治兵衛某

(26) 元禄元 $\cdot 12 \cdot 21$ 青木勘次郎(弥三左衛門信壽?)

27 元禄元 $\cdot 12 \cdot 21$ 中川武右衛門直茂

(28) 元禄元・12・21 野田源右衛門某

29 元禄元 $\cdot 12 \cdot 21$ 室七郎左衛門重福

30 元禄元 $\cdot 12 \cdot 21$ 細田伊左衛門時矩

(31) 元禄元・12.21 神尾五郎兵衛(助左衛門茂次?) 小

32 元禄元 $\cdot 12 \cdot 21$ 比企儀左衛門某

(33) 元禄元 $\cdot 12 \cdot 21$ 柘植善九郎正休

34 元禄元 $\cdot 12 \cdot 21$ 平岡市右衛門資明

33 元禄元 $\cdot 12$ 伴善大夫政忠

36 元禄元 $\cdot 12 \cdot 21$ 平岡四郎左衛門道祐

37 元禄元 $\cdot 12 \cdot 21$ 井戸平左衛門正明

(38) 元禄元 $\cdot 12 \cdot 21$ 平岡彦左衛門道高

(39) 元禄元 $\cdot 12 \cdot 21$ 桜井七右衛門政蕃

40 元禄元 $\cdot 12 \cdot 21$ 望月忠左衛門為直

(41) 元禄元・12・21 野田彌惣左衛門久忠

(42) 元禄元・12.21 河田宇右衛門宜繁

(43) 元禄元 $\cdot 12 \cdot 21$ 武藤十郎兵衛安利

44 年月不詳 计傳五左衛門(辻源五右衛門守言)

(45) 元禄元 $\cdot 12 \cdot 21$ 平井太郎左衛門次方

46 元禄元 $\cdot 12 \cdot 21$ 長谷川庄兵衛長貴

(47) 元禄元 $\cdot 12 \cdot 21$ 古川武兵衛氏成

48 元禄元 $\cdot 12 \cdot 21$ 岡田庄大夫俊陳

49 元禄元 $\cdot 12 \cdot 21$ 石井治大夫定次

50 元禄元 $\cdot 12 \cdot 21$ 長谷川甚兵衛安茂

(5) 元禄元 $\cdot 12 \cdot 21$ 窪嶋市郎兵衛長敬

(52) 元禄 $6 \cdot 2 \cdot 6$ 増嶋佐七郎重信

(53) 元禄 $6 \cdot 2 \cdot 6$ 竹村彌大夫嘉武 (54) 元禄 $6 \cdot 2 \cdot 6$ 服部八右衛門保孝

$\begin{array}{lr}\text { 勘定 } & 100 \text { 俵3 } \\ \text { 勘定 } & 180 \text { 俵 }\end{array}$

勘定 150 俵

不明不明

勘定組頭年

$\begin{array}{lr}\text { 勘定 } & \text { 不明 } \\ \text { 材木石奉行 (元勘定) } & 200 \text { 俵 }\end{array}$

小細工頭不明

支配勘定 /小普請 /三丸張番 不明

不明不明

表火番/徒目付不明

勘定組頭 400 俵

残物奉行 /川船奉行 30 口

支配勘定 200石

勘定

支配勘定 不明

支配勘定否明

勘定 150 俵

勘定 150 俵

勘定 150俵

勘定 100俵3口

勘定 100俵3口

支配勘定／油奉行否明

小普請（元勘定） 100 俵

$\begin{array}{ll}\text { 勘定 } & 200 \text { 石 } \\ \text { 小普請 (元勘定) } & 150 \text { 俵 }\end{array}$

150 俵

勘定 150俵5口

勘定 150 俵

小普請（元勘定） 230 俵余

勘定 150俵

勘定 150 俵

勘定組頭 200 俵

条蔵奉行（元勘定）100俵3口

$\begin{array}{ll}\text { 代官（元勘定） } & 100 \text { 俵 } \\ \text { 小普請 (父が勘定) } & 150 \text { 俵 }\end{array}$

林奉行（元勘定） 150 俵

勘定組頭 250俵

大坂蔵奉行（元勘定）150俵5口

勘定 150 俵

材木石奉行（元勘定） 200 俵

勘定 150俵

勘定 150 俵

林奉行（元勘定） 150 俵

勘定 100俵?口

勘定 150 俵

勘定 150 俵

漆奉行（元勘定） 150 俵

勘定 100 俵

勘定(残物奉行・川船奉行兼任) 150 俵

150 俵

150 俵

番号は図 2 と対応。白抜き番号は旧「館林藩士」を示す。屋敷受領日は『屋敷証文』、

拝領者の諱・役職・家禄高は『寛政譜』による。

拡張している。渋谷は、この添地は寛文元年に倍増した家臣団の宅 地確保のために用いられたとするが、妥当な推定であろう。

このことは『場末沿革図書』の該当部分を見るとよくわかる（巻 20 元上の第 $6 \cdot 9 \cdot 10$ 区画、下の第2 5区画に相当)。図 1 は「元禄十一 寅年之形」(巻20元下第2区画のみ「元禄十一寅年同十二卯年之形」) を もとに作成したもので、実線が元禄 11 年頃の敷地割、破線が同年 に御殿が拡張される以前の敷地割を示している。これによれば、当 初の拝領部分とみられる南〜南西側に大きな面積を占める街区があ り、添地された部分とみられる北〜北東側に長方形状の街区がとら れていることがわかる。この形状からすれば、前者が御殿や庭園か らなる、いわゆる「御殿空間」にあたり、後者が「藩士」たちの居 住する「詰人空間」にあたっていると考えられる ${ }^{31)}$ 。実際、前者 は幕府の小石川御殿に転用され、後者はそのまま旧綱吉家臣団の屋 
敷として利用された。この点は『場末沿革図書』巻 20 元下、第 2 区画に扣いても次のように記されている(亀甲括弧内は原割注を示す) 延宝年中は館林殿屋敷内二候処、其後天和元西年中 徳松君様西丸え 御入後、右御屋敷跡地之内当所上り西南之方 は年月不詳御殿地〔小石川称御殿〕二成、右御殿地二相成候残 地、当所御屋敷跡地之内二前々 5 住居来候者其儘屋敷拝領いた し、且御長屋住居之者も其儘御長屋拝借いたし候儀と相見、天 和年中之頃は同所之内二夫々道敷有之、東手二明地壱ヶ所・御 長屋二棟、東南中程同一棟有之、其外惣躱小屋鋪二候

この記述について、実際に『場末沿革図書』に記された扯領者名を もとに検討してみたい。表 5 は、元禄 11 年時点で小石川下屋敷跡 地に名前が見えるなかで、『寛政譜』で履歷が確認できる拝領者計 43 人を整理したものである。このうち『屋敷証文』などで授受が 確認できるのは 9 人のみで、それ以外の大半は「館林藩」時代か ら拝領していた人物と推定できる。実際、34人中18、(21)、(24)、(30) を除く 30 人は神田屋敷に勤仕していたとの記載を確認できる（例 外の 4 人については、該当の拝領記事が『屋敷証文』の欠年に当たってい るか、『寛政譜』の情報が欠落している可能性もあるが、不詳である)。し たがって先の『場末沿革図書』の記述は裏付けられたといえよう。

次に、「館林藩」廃藩後に新たに拝領したとみられる9人につい てみると、このうち 7 人も旧「館林藩士」であったことも確認される。 残る 2 人も三丸勤仕者であり、すでに「藩」が解体された後であっ てもなお下屋敷の跡地には綱吉関係者が集まってきていたことがわ かる。この点は『寛政譜』では確認できないものの『屋敷証文』な どで役職の判明する小禄の土についても同様であり、綱吉母桂昌院 の居所である三丸への勤仕者の拝領事例が多数見られる。

このような旧下屋敷の空間的規定性は屋敷の範囲内のみにとぞま らなかった。例えば本節で挙げた旧「藩士」の拝領事例(4)と (5)でふ れた小石川白山に打ける屋敷受領は、旧下屋敷内ではないものの、 そのすぐ近隣地での事例であった。旧「藩士」の集住はかつての屋 敷の外側にも広がっていたのである。

\section{本所石原蔵屋敷}

本所石原蔵屋敷は綱吉が万治 3 （1660）年に拝領したもので、隅田 川左岸に位置している。『場末沿革図書』巻 15 下第 $2 \cdot 3$ 区画の「延 宝年中之形」を見ると「館林殿御蔵屋敷」と記されるのみで空白と なって扣り、内部構造は不明であるが、屋敷南境に「入堀」があり、 つづく第 2 区画の「元禄元年辰年之形」・第 3 区画の「元禄元辰年 同録西年之形」を見ると、南北に三筋、櫛形状の船入が残存してい ることがわかるので (図 2 参照)、蔵屋敷の機能からすると、この船 入周辺には年貢米などの産物の荷揚げのための空間と蔵、拉よび役 所が設けられていたものと推察される。

この蔵屋敷が、綱吉の将軍就任後にいかに変容したかについて検 討したい。図 2 は上述の『場末沿革図書』をもとに、元禄6 (1693) 年頃の蔵屋敷跡の街区を復元したものである。そしてそこに記さ

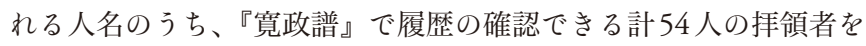
示したのが表6である。これを見ると、ほとんどの屋敷は元禄元年 と6年に割付がなされたものであることがわかる。『場末沿革図書』 巻 15 下第 2 区画の説明文には、

右一円之地所延宝年中は館林殿御蔵屋敷 - 徳山五兵衛屋敷等二 有之由二候得共詳ならず、其後御蔵屋敷御取払二成候由、元禄
元辰年十二月御蔵屋敷跡地之内二而、久下作左衛門……

と見え、蔵屋敷にあった諸建造物はいったん撤去され、元禄元年 12 月に跡地に屋敷の割付が行われたことがここでも示されている。

一方で屋敷授受の年月日が確認されない拝領者も 10 人確認され るが、例えば(4)清水と（の岡田は上掲の史料において、

同所（引用者注：弁天社地）続二而年月詳ならず岡田五右衛門手 前書細田三右衛門屋敷続二而清水庄九郎両人屋敷二成、

と記され (原文割注省略)、他も同様に「年月不詳」の拝領とされて いること、小石川白山屋敷のように旧「藩士」がそのまま屋敷内居 住を継続した旨の文言が見えないことから、拝領の記録が久落した 結果であると解しておきたい(表 6 では屋敷受領日を「年月不詳」として、 表 5 の場合と区別する)。

このように、本所石原蔵屋敷は綱吉の将軍就任後に一度解体され 再開発されるという道を辿ることになったが、これは単に「館林藩」 が廃藩になったことによるのみならず、第3節でふれたような、天 和2（1682）年〜貞享5（1691）年の本所撤退策も大きな要因として 働いていたと考えられる。

興味深いのはこの新たに開かれた屋敷地を拝領した幕臣である。 すなわち、表6の54人のうちのほとんぞが勘定方またはその出身 者であり、また6割弱にあたる32人は旧「館林藩主」であったと いう点である。蔵屋敷は領内の年貢米や特産物を貯蔵販売する場所 であり、「館林藩」時代には勘定方の家臣が多く勤仕していたと推 測されるが、その蔵屋敷が解体され新たに再開発がされるという過 程を経てもなお、その跡地は旧「藩士」を多く含む勘定方幕臣の集 住地に立ち返ることとなったのである ${ }^{33)}$ 。

\section{5. 綱吉政権と武家地}

本稿では、徳川綱吉政権期を対象として、江戸の武家屋敷に対して ぞのような政策がとられてきたかを概観し、とくに綱吉の将軍就任 にともなって幕臣に編入された家臣たちの屋敷がどう扱われてきた かについて考察してきた。その要点は以下のようにまとめられる。

(1) 将軍就任前の徳川綱吉は上野館林に 25 万石を与えられた家門 大名であった。家臣の約6割は幕府からの附属者で、形式上で は「藩士」でありながらも幕府からの出向者としての側面も持ち、 一般の幕臣と同様に江戸に独立した屋敷を拝領する者もいた。

(2) 延宝8（1680）年に綱吉が徳川宗家を継ぐと、その家臣団も幕 臣に編入されるが、天和3（1683）年までは「館林藩」は形式的 に残されたため、ほとんどの家臣は幕臣でもあり「館林藩士」で もあるという二重身分状態に胁かれていた。

(3)そのため、綱吉家臣団は一部の側近層を除けば基本的にかつて の館林家屋敷（主として小石川白山下屋敷）の屋敷をそのまま拝領 屋敷として居住を続けていた。本所石原蔵屋敷はいったん解体さ れたが、元禄元 (1688) 年に再度屋敷割がなされ、旧「藩士」を 多く含む勘定方の屋敷地となった。こうして、「館林藩」が消滅 した後であっても、小石川と本所の屋敷跡とその周辺は旧「藩士」 が多く集まる屋敷地として再編されたのである。

(4) 綱吉政権では天和2（1682）年に本所撤退策を発するなぼ、当 初は江戸の範囲を集約する方針を打ち出していたが、貞享5 （1688）年にこの政策を撤回する。その後は逆に災害などを契機 とした武家屋敷の周縁部への移転事例も散見されるようになり、 
江戸のスプロールが進展していく。旧「藩士」にはこうした周縁 部に屋敷を拝領した者も少なからず確認された。

最後に、綱吉と同様に養子となって将軍職を継いだ家宣と吉宗のと きの家臣団の編入と屋敷付与のあり方と比較してまとめにかえたい。 綱吉の場合と近いのは家宣の事例である。家宣はもと綱豊といい、 父綱重から甲府 25 万石（のち延宝8［1680］年に 10 万石加増）を継承 していた。この「甲府藩」も家臣の多くが幕府からの附属者であり、 一部の家臣は江戸に独立した屋敷を拝領していたなに゙、「館林藩」 ときわめて類似した性格を有していた。

綱豊の場合、養子になってから実際に将軍を継ぐまでに 4 年以上 の移行期間があり、西丸に入った段階で「甲府藩」は廃藩になった という点で綱吉の場合と異なっている。ただし幕臣に編入された家 臣団の屋敷の動向については綱吉の場合と同様に甲府家屋敷跡が彼 らの居住の受け亚として機能して扣り、それ以外では市中で生じた まとまった上がり地などが活用されていた。

一方でこれらと異質なのが吉宗の事例である。吉宗は正徳6 (1716) 年に和歌山藩から徳川宗家を継いだが、このさい彼は 200 名余の家臣団を選んで江戸に供奉した。そのため綱吉や家宣の場合 と比べて編入される家臣団の規模は小さいが、問題は和歌山藩を残 存させたために江戸に移住させる家臣団の居住の受け皿がなかった ことである。したがって吉宗政権の成立期には、とくに側近層を中 心に屋敷地の強権的な置き換えが行われることになる。

このように養子としての将軍家継承と家臣団編入という共通性を もちながらも、その編入家臣団の屋敷地の動向には差異があり、そ こには政権の形成過程やそれぞれの時代の江戸武家地の状況も大き く関わっている。政権交代と武家屋敷の関係については、18世紀 以降の構造的変容 ${ }^{34)} も$ 見据えながらさらに事例研究を行っていく 必要性があるが、今後の課題として扣きたい。

\section{謝辞}

英文要旨・要約作成にあたっては明石工業高等専門学校のピチニニ 東野アドリアナ氏のご協力をいただきました。また本研究はJSPS 科研費 24360255 の助成による成果の一部です。ここに記して感謝 いたします。

\section{注}

1）明治2（1869）年の調査による。宮崎勝美「江戸の土地一大名・幕臣の 土地問題」吉田伸之編『日本の近世9 都市の時代』(中央公論社、1992年)、 130 頁。

2）鈴木賢次「旗本住居の都市における存在様態」『建築史学』第2号（1984年）、 宮崎勝美「江戸の武家屋敷地」高橋康夫·吉田伸之編『日本都市史入門 I 空間』 (東京大学出版会、1989年)、同上宮崎論文。

3）武家地に関する研究史整理としては、藤川昌樹『近世武家集団と都市・建 築』(中央公論美術出版、2002年)、岩淵令治『江戸武家地の研究』(塙書房、 2004年）がある。なおこれ以降の重要な研究書としては、江戸遺跡研究会 編『江戸の大名屋敷』(吉川弘文館、2011年)、作事記録研究会編『大名江 戸屋敷の建設と近世社会』(中央公論美術出版、2013年) などがある。

4) 松本剣志郎「若年寄役屋敷の交替拝領 $と$ 武家社会」『白山史学』第 42 号 $(2006$ 年)、同「土浦藩江戸屋敷について—老中役屋敷の成立」『土浦市立博物館 紀要』第23号 (2013年)。

5）深井雅海『江戸城——本丸御殿と幕府政治』（中公新書、2008年）は、幕
府政治のありようを江戸城の空間構造との関連で解き明かしている点で注目 されるが、この議論をいかに都市スケールまで拡げるかが課題となろう。

6）拙稿「紀州藩士の幕臣化に伴う江戸屋敷獲得動向」『日本建築学会計画系 論文集』第561号 (2002年)、同「武家地の空間とその流動性——徳川家宣 政権期を事例として」近藤和彦・伊藤毅編『江戸とロンドン』(山川出版社、 2007 年)、同『江戸の政権交代と武家屋敷』(吉川弘文館、2012年)。

7）上記拙著では綱吉政権初期（貞享期まで）の動向について簡単にふれてい るが、本稿は綱吉政権全体を対象としてょり詳しい分析を行うものである。

8）『常憲院殿御実紀』など公的史料では通常四男とされるが、福田千鶴は「長 子」家綱誕生前の寛永9（1632）年2月に男子が生まれたものの間もなく薨 じた事実があったことを指摘している。福田『徳川秀忠——江が支えた二代 目将軍』(新人物往来社、2011年)、126 128 頁参照。

9）以上は『常憲院殿御実紀』巻一による。刊本『徳川実紀』第五篇（吉川弘文館、 1976年)、353頁。

10）深井雅海『徳川将軍政治権力の研究』(吉川弘文館、1991 年)、第 2 編第 1 章（初出1977年）参照。

11）国立公文書館内閣文庫所蔵。

12）国立国会図書館所藏。

13）筆者は以前に御三家の一つである水戸藩を事例として、藩主が江戸定府 であったがために江戸に常住する藩士がしだいに増加し、城下町水戸の空洞 化が進んでいく過程を論じたが、「館林藩」はそのさらに極端な事例といえ る。拙稿「水戸藩に打ける定府進展に伴う城下町および江戸藩邸の変容」『日 本建築学会計画系論文集』第560号（2002年）参照。

14) 前注 10 深井書、161頁。

15）『東京市史稿』市街篇の巻と頁圭示す。以下同様。

16) 前注 10 深井書、161頁。

17）この点は 3 代将軍家光の弟忠長の家臣団、綱吉の兄綱重の家臣団とも共通 する。前注6拙著、43〜44、87頁参照。

18）元禄6（1693）年に本所奉行が復活したことによるものか、元禄 7 年〜正 徳3（1713）年の写本では「本所之部」が他の地域と分けてまとめて揭載さ れている。

19）龍之口と大名小路の一部、本所の横川以東、竪川以南、深川全域を欠く。

20）『甲子夜話』では享保7（1722）年時点での大名・旗本・御家人の総人口 を22,868人としている。

21) 『常憲院殿御実紀』巻五、前注9刊本、4 40 頁。

22) 前注 6 拙稿 2007 年論文。

23）『常憲院殿御実紀』巻一、前注9刊本、355頁。

24) 前注 10 深井書、166 167頁。

25）同上、167 170頁。

26）『天和日記』ほか。『東京市史稿』皇城篇第2（東京市、1912年）、362頁。

27) 『常憲院殿御実紀』巻六、前注 9 刊本、464頁。

28）『常憲院殿御実紀』巻廿三、元禄4（1691）年2月3日条に「佐藤三左衛 門信勝は神田御殿番となり……とあるのが初見であるが、同役職の設置時 期については不詳。刊本『徳川実紀』第六篇（吉川弘文館、1976年）、97頁。 29）本節での旧「藩士」屋敷の検討からも明らかなように、この柳沢の神田 御殿拝領前後に旧「藩士」の目立った屋敷拝領の動きは見られない。したがっ て少なくとも神田御殿の末期には旧「藩士」はすでにほとんぞ居住していな かったとみるべきであろう。

30）渋谷葉子「「小石川植物園」の土地利用に関する歴史的変遷」『東京大学 構内遺跡調査研究年報』第5 号 (2006年)。

31）「御殿空間」と「詰人空間」の二元性については、吉田伸之『巨大城下町 江戸の分節構造』（山川出版社、1999年）補論4（初出1988年）考参照。

32）例えば注 28 で挙げた神田御殿番佐藤三左衛門信勝は旧「館林藩士」では なく、幕府神田御殿勤仕者と「館林藩」神田屋敷勤仕者とは必ずしも重なら ないことに注意を要する。

33）な技表6の旧「藩士」が本所に屋敷を择領する前の居所については記録が 見られない。本所撤退期においては神田屋敷などが受け典となった可能性も あるが、不詳である。

34）山端穂がすでに指摘しているように、幕府による拝領屋敷の下賜は享保 期を劃期として減少に向かうといい、幕府政治動向と武家屋敷との関係にも 変化が生まれてくると予想される。山端「江戸幕府の拝領武家屋敷下賜の実 態」竹内誠監修・大石学編『都市江戸への歴史視座一大江戸八百八町展 武家拝領地・江戸首都論』(名著出版、2004年) 参照。 


\section{RELATION BETWEEN SAMURAI LAND (BUKECHI) POLICY AND SHOGUN'S RETAINER ADMISSION DURING TOKUGAWA TSUNAYOSHI GOVERNMENT PERIOD}

\section{Kaoru IWAMOTO*}

*Lect., Faculty of Design and Architecture, Kyoto Institute of Technology, Dr. Eng.

This paper analyses the samurai residence policy during the Edo Shogunate $5^{\text {th }}$ General, Tsunayoshi Tokugawa administration period (1680 through 1709). The Historical materials used in this analysis were the record of Samurai residence land movement, Edo illustrated map and the Edo Shogunate retainers genealogies.

Tokugawa Tsunayoshi was born in 1646, as the younger brother of the $4^{\text {th }}$ Tokugawa Shogun Tokugawa Ietsuna. In 1661 Tsunayoshi received the Kozuke Province and became the feudal lord of the Tatebayashi clan, wealth of 25,000 Koku. Since he was the Shogun nearest relative, Tsunayoshi and most of his vassals lived in Edo. Approximately 60\% of his vassals were attached by the Shogunate, and although at that time formally they were retainers of the Tatebayashi clan many of them originally were Shogunate retainers. Tsunayoshi's Tatebayashi clan vassals were treated almost as a regular Shogunate retainer, and some of them even received an independent residence in Edo.

In 1680 Tsunayoshi's elder brother Ietsuna adopted Tsunayoshi because he was childless and his health in a critical condition. Consequently Tsunayoshi was now the heir of Edo Shogunate. Tsunayoshi became Shogun and his son, Tokumatsu was the new feudal lord of the Tatebayashi clan. Most of Tsunayoshi former vassals were admitted as Shogunate retainers, and since the Tatebayashi clan still existed, many vassals were both Tatebayashi clansman and shogun's retainer. Therefore when Tsunayoshi became Shogun only a few number of vassals, the one closest to Tsunayoshi, received a new residence in Edo, most of his vassals continued to live in their former residences.

As a feudal lord of the Tatebayashi Clan Tsunayoshi received three residences: a Kamiyashiki (main residence) in Kanda, a Shimoyashiki (Suburban residence) in Koshikawa-Hakusan and a Kurayashiki (warehouse residence) in Honjo-Ishihara. Among these residences the Shimoyashiki in Koshikawa-Hakusan was probably the one to lodge the bigger number of vassals, which would continue to live there even after they became shogun's retainers. The Kurayashiki in Honjo-Ishihara was demolished after Tsunayoshi became shogun. The warehouse residence was on the east bank of the river Sumida, and it function was to store land tax rice. After that, in 1688 the area was re developed as residence land for accounting officers, some of which were former Tatebayashi Clansmen. Despite the fact that, with the death of Tokumatsu in 1683 the Tatebayashi clan was abolished, several former vassals continued to live in the area near the Koshikawa-Hakusan Shimoyashiki and the Honjo-Ishihara Kurayashiki.

What happened with Tsunayoshi residences is related to all Samurai land transformation in the whole city of Edo. When Tsunayoshi became shogun he tried policies to reduce the urbanized area of Edo but soon he was forced to give up. As a result the urbanized area of Edo spread incredibly, and the area of Samurai's houses on the suburbs spread too. As we have seen many of the former vassals of Tsunayoshi received residences on this newly urbanized area. In conclusion through the analyses of the change on Samurai's residence land this paper clarifies the relation between Tsunayoshi's government policies and Edo urban development. 
